Journal of Management and Economic
Studies
$\begin{aligned} & \text { 2019, 1(3): 10-17 DOI: } 10.26677 / T R 1010.2019 .93 \\ & \text { Journal Homepage: } \text { https://wWw.jomaes.org }\end{aligned}$

\title{
Result Of Investment And Product Development Bearing Geographical Indications: Research Lychee Products In Vietnam
}

\author{
Le Thi Yen \\ Thai Nguyen University of Economics and Business Administration, Vietnam \\ Pham Minh Hoa \\ The ministry of Finance, Viet Nam
}

\begin{abstract}
This study was conducted to analyze the results of Investment and Development in lychee products in Vietnam. In particular, the study compared the difference about results of development investment between two groups with geographical indications and no geographical indication. The Research findings are used as a basis for proposing recommendations to improve results of products development investments with geographical indications in Vietnam.
\end{abstract}

Keywords: Development investment, lychee, Vietnam, geographical indications, results of development investments

\section{Introduction}

The diversity of natural conditions, culture and ethnicity have given Vietnam a lot of specialty products, traditional products bearing culture of ethnic groups, local, made special character and originality of the country of Vietnam. With that potential, the development of sustainable products not only has advantages in terms of economic significance (Improve livelihoods, create jobs for the people ...) but also a deeply social significance in view of social stability, poverty reduction, political stability.

The potential of the products is very large, but the development of specialty products more difficult, challenging, according to Nguyen Mai Huong (2013) Research on the status of development of specialty products in the northern mountainous region pointed out the difficulties in the development of specialty products are: i) many local specialties in the northern mountainous region are only produced on a small scale, with no consistent process and investment orientation; ii) There are no solutions on site processing, harvesting technology, processing and preservation are rudimentary; iii) The quality of specialties is unique, but not 
really uniform, stable and sustainable; iv) No organized system of professional consumption, stability, product competition by counterfeit goods, pirated goods on the market.

However, besides the achievements, agriculture still exists and limited: the forms of organization of production is slow to reform; agricultural production in many places is still fragmented, lack of links; rural environmental pollution in many places is still serious; life of a part of people, especially in remote areas still difficult; food safety and hygiene is still a pressing issue; unsustainable agricultural and rural industries, difficulties in the context of international economic integration

In that context, agricultural development orientation needs to take into account the appropriate access strategies, focusing on two main development axes:1) production and market access for agricultural products in large numbers and popularity, applied science and technology, advantages in large-scale goods producing ; 2) produce and access markets with traditional, specialty products, quality and high added value based on regional advantages, cultural traditions and the accumulation of skills of the people. Along with each orientation are different solutions that can promote commercial development, use appropriate measures for the protection of intellectual property to support the sustainable development of agricultural commodities

Vietnam has focused on developing strategic product bearing the geographical indication as a solution to build a brand for agricultural products, improve the value and effectiveness of agricultural production, as of December 30, 2016, Vietnam has protected 48 geographical indications, including 4 geographical indications of foreign countries and 44 geographical indications of Vietnam

Lychee is one of the agricultural products protected by geographical indications in Vietnam, but these products are protected according to certain geographical indications. Therefore, there are differences in development investment and results of development investment between group with geographical indications and no geographical indications. This study was conducted to analyze the results of product development investment with geographical indications compared with without geographical indications to propose recommendations to further improve the results of lychee products development investment in Vietnam

\section{Overview of research}

Investment in agricultural development, the influence of agricultural products on socioeconomic development has received the attention not only of researchers but also of policy makers: Dominique Barjolle et al (2009) focused on methods to assess the impact of territorial geographical indications (economic, social and environmental), the results show that economic benefits are is the only engine in implementing product protection projects with geographical indications.The results show that these economic benefits is only purpose in implementing product protection projects with geographical indications.

Or in view of the Carina Folkeson (2005) the authors consider the economic impact of the geographical indication to object is the manufacturer. The research findings also show that the production of products bearing geographical indications in the EU has in many cases contributed to rural development, although the development is different between regions and different products. The study also concluded that statutory protection is necessary for benefits arising from the production geographical indications to benefit producers and related actors. The research results show that Basmati rice is more profitable than other crops, after that, the author studies the factors affecting the decision to produce products bearing geographical indications, one of the number of factors mentioned is the ability to access policies and the 
number of workers in the household.

Pradyot R. Jena and Ulrike Grote, (2010) used data from a survey of 300 rice farmers in a province of northern Indian namely Uttarakhand. In the study, the author analyzes the total profit, determines the net benefits of Basmati rice bearing geographic indications with other plants in the same locality but does not have a production certificate with specific geographical indications. The author chooses crop that do not have geographic indications certification as sugarcane....Simultaneously, the author has used the marginal benefit analysis method as a basis for conducting this research, straight line regression (OLS) used by the author to analyze the impact of geographical indications.

Le Dinh Thang (1993), Nguyen Sinh Cuc (2001) in their research, there were opinions about production households, each study has different specific views about production households, but in common, it is agreed that production households are units which participate in the production of mining activities, processing products related to agriculture.

Some other studies conducted to determine the factors affecting the income of households in specific areas, in different localities such as: Nguyen Quoc Nghi et al (2011), Nguyen Van Thieu et al (2011), Nguyen Van Toan et al (2012), Huynh Thi Dan Xuan (2012), Nguyen Thi Hong Hanh et al (2013) ...Primary data is also selected by the authors for their research, this is also the most obvious similarity to the studies related to considering factors affecting household incomes, specifically here are the farm households agricultural production studied by the authors. The purpose of the studies: to determine the average income of households, and the factors affecting household income, the relationship between them. With the data collected, the author conducted the analysis using descriptive modeling and statistical methods, the models used were OLS models, this is a model which is relatively popular with research in Vietnam regarding factors affecting household's income in different fields

\section{Research methodology}

\subsection{Data collection methods}

Information data for the statistical analysis in this chapter is collected from household interview by using standardized questionnaires.

The production households selected for the survey must ensure the following conditions:

Firstly, for households producing Litchi products bearing geographical indications make sure that producers have a detailed record of revenues and expenditures in the production process, the percentages between each group produce in comply with the overall percentage of households producing products with geographical indications of the locality.

Secondly, the survey of households producing lychee products of some other typical areas in Bac Giang province, Vietnam such as Yen The and Luc Nam districts, to compare the comparison between lychee production group with geographical indications and the group producing products without geographical indications. The number of survey samples ensures that the proportion of households production with geographical indications and households production does not have geographical indications.

Time for survey: From January 2018 to the end of May 2018.

+) Number of samples:

There are many different concepts about the sample, according to Nguyen Van Thang's point of view (2014), the minimum number of samples that can perform statistical operations is 100 . 
According to Nguyen Dinh Tho and Nguyen Mai Trang (2007), the sample size must be at least 4-5 times the number of variables in the questionnaire

Accordingly, the authors conducted a survey after cleaning ensures data and minimum number of samples collected to perform statistical calculations of 100 observations for the study.

The author chooses a convenient sampling to use in the study sample, because: Sampling is based on convenience or based on the accessibility of the object, so access to the survey subjects is relatively easy. Convenient sampling is often used in research to discover, to determine the practical meaning of the research problem; or to check the questionnaire in advance to complete the board; or when you want to make a rough estimate of the problem in question, you don't want to spend a lot of time and money. However, convenient sampling also has limitations, the sampling entirely depends on the experience and the overall understanding of the researcher, so the survey results are often subjective of the researcher. On the other hand, we can not calculate the error due to sampling, so it is difficult to apply statistical estimation method for extrapolating the results for the overall sample above. Primary data collection process is done as follows:

Authors used direct survey methodology to collect information on households and use the survey method directly associated with collecting information relating to income, factors affecting the production of household income, investment in the development of household production. With households author not meet directly, by choosing one of two options as follows:

Option 1: Return the survey and return to the survey after 1 week;

Option 2: Authors choose different households, economic conditions and other characteristics similar to select interview instead.

After collecting information, the authors carried out data cleansing, in the case of sample surveys after cleaning does not guarantee enough minimum number of samples, author interviews followed to ensure the survey sample size sufficient to meet the minimum requirements to perform the statistical analysis. In addition, for the households interviewed, author always tried to balance the proportion of the survey and ensure the representation between the two groups produce products with and without geographical indications for lychee products

The author conducted a survey with 300 representatives of households in which 150 individuals representing the producer group Luc Ngan lychee with geographical indications and 150 individuals representing in group of producer products without geographical indications

After collecting survey questionnaires, input data into excel software, the author removes the survey forms that do not meet the requirements of data for the research, retains the completed questionnaires to request information to perform statistical analysis. 188 surveys were clean and meet the performance requirements of statistical analysis, the authors used observations performed 188 analyzes for the study, number of observations meet the requirements for the minimum number of observations to study the implementation of statistical analysis

\subsection{Data analysis Methods}

The collected data will be calculated and analyzed, the descriptive statistical method and the comparative method used by the author in this study. The calculated results will be interpreted to analyze the issues itudied. 


\section{Research findings}

\subsection{Average production yield lychee products}

As one of the typical products of Bac Giang province, Vietnam, (Vai Thieu) lychee received the attention of local authorities at all levels to focus on product development. At the same time, the local population is also considered as one of the main products, generate income for people. To achieve certain results for the local lychee brand, development investment has an important position and role, specifically: About lychee production according to survey results from households as follows:

Table 1: Lychee output

\begin{tabular}{|l|c|c|c|c|c|}
\hline \multicolumn{7}{|c|}{ Descriptive Statistics_with geographical indications } \\
\hline & $\mathrm{N}$ & Minimum & Maximum & Mean & Std. Deviation \\
\hline Output & 96 & 950 & 4100 & 1624.36 & 642.573 \\
\hline $\begin{array}{l}\text { Valid N } \\
\text { (listwise) }\end{array}$ & 96 & & & & \\
\hline \multicolumn{7}{|c|}{ Descriptive Statistics_without geographical indications } \\
\hline \multicolumn{7}{|c|}{ N } & Minimum & Maximum & Mean & Std. Deviation \\
\hline $\begin{array}{l}\text { Output } \\
\text { Valid N }\end{array}$ & 92 & 605 & 3100 & 1175.90 & 441.748 \\
\hline
\end{tabular}

Source: Analysis results from the author's research data

Lychees output in two groups producing products with geographical indications and without geographical indications. The group with geographical indications has much higher yields than the group without geographical indications.

Specifically, the group with geographical indications has an average yield of 1624.36 quintals per crop (the lowest is 950 and the highest is 4100 quintal / crop); the group without geographical indications has an average yield of 1175.90 quintals per crop (the lowest is 605 and the highest is 3100 quintal / crop), lower than 448.46 quintals compared to the group with geographical indications. The cause of this phenomenon due to the difference in product quality, product price when the supply to the market ... Especially with products bearing geographical indications, natural conditions have a very important role, great incentives for Luc Ngan to become a brand for famous lychee products both at domestic and abroad. Requirements for Luc Ngan lychee product also much higher with the cultivation and care of lychee accordance with regulations, compliance right dose of plant protection, fertilizer, harvesting on time ... thereby creating good quality lychee, higher output. For products with geographical indications, with the advantage of quality as well as price, lychees becomes the main production product of the local households, is the main source of income for the household, therefore, the survey results also show the advantage of average production between two groups of households with geographical indications and without geographical indications.

\subsection{Scale of average invested capital}

To obtain such results in the production of local lychee products for both groups with geographical indications and groups without geographical indications, scale investment capital 
has a relatively large impact. The results of investment size of each group producing products with geographical indications and groups without geographical indications are as follows:

Table 2: Scale of investment capital

\begin{tabular}{|l|c|c|c|c|c|}
\hline \multicolumn{7}{|c|}{ Descriptive Statistics_with geographical indications } \\
\hline & $\mathrm{N}$ & Minimum & Maximum & Mean & Std. Deviation \\
\hline investment & 96 & 232 & 282 & 264.46 & 10.296 \\
\hline $\begin{array}{l}\text { Valid N } \\
\text { (listwise) }\end{array}$ & 96 & & & & \\
\hline \multicolumn{7}{|c|}{ Descriptive Statistics_without geographical indications } \\
\hline & $\mathrm{N}$ & Minimum & Maximum & Mean & Std. Deviation \\
\hline investment & 92 & 83 & 193 & 117.30 & 31.064 \\
\hline $\begin{array}{l}\text { Valid N } \\
\text { (listwise) }\end{array}$ & 92 & & & & \\
\hline
\end{tabular}

Source: Analysis results from the author's research data

According to the survey data, it was found that the group of households with geographical indications spent much more investment cost than the group without geographical indication, specifically:

Table 3: Types of Investments

Unit: Millions dong.

\begin{tabular}{|l|c|c|}
\hline Investments & $\begin{array}{c}\text { Group with } \\
\text { geographical } \\
\text { indications }\end{array}$ & $\begin{array}{c}\text { Group without } \\
\text { geographical } \\
\text { indications }\end{array}$ \\
\hline 1. Regular investment & $\mathbf{2 2 9 , 0 6 0}$ & $\mathbf{9 7 , 6 5}$ \\
\hline Labor investment & 100,450 & 44,63 \\
\hline Fertilizer Investment & 21,650 & 11,82 \\
\hline Trimming Investment & 25,510 & 8,15 \\
\hline Harvest Investment & 81,450 & 33,05 \\
\hline $\begin{array}{l}\text { 2. Initial investment (machinery and equipment) - } \\
\text { fixed investment }\end{array}$ & $\mathbf{3 5 , 3 4}$ & $\mathbf{1 9 , 6 5}$ \\
\hline Total investment & $\mathbf{2 6 4 , 4 6}$ & $\mathbf{1 1 7 , 3 0}$ \\
\hline
\end{tabular}

Source: Analysis results from the author's research data

It can be seen that the regular investment is the highest proportion of investment in both groups of households, for groups with geographical indication regular investment is 229.060 millions; the group without geographical indication with regular investments is 97.65 million. In the regular investment group, the investment in labor accounts for the largest proportion because it is quite agricultural work, needs the care, improvement and collection of human. Next is to invest in harvesting, when going to the main crop, the people who go to harvest the lychee to rent lychee rent in Luc Ngan, so the price of labor also increases. If in previous years, the rent of each laborer is from 130 to 150 thousand VND / day, this year from 200-250 thousand VND / day. 
Regarding initial investments - fixed investment in lychee growing industry, Fixed investments often invest in water pumps, irrigation systems, pruning tools and fruit collection tools ... Group with geographical indications fixed investment is 35.34 million average, the group without geographical indication has fixed investment of about 19.65 million.

\subsection{Effect of investment in developing lychee}

With the lychee development investment of the group without geographical indications and geographical indications, the investment efficiency of the two groups is different, as follows:

Table 4: Net profit of lychee producers

Unit: Millions dong

\begin{tabular}{|l|c|c|}
\hline \multicolumn{1}{|c|}{ Result } & $\begin{array}{c}\text { Group with geographical } \\
\text { indications }\end{array}$ & $\begin{array}{c}\text { Group without geographical } \\
\text { indications }\end{array}$ \\
\hline 1. Investment & 264.46 & 117,30 \\
\hline 2. Income & 365,54 & 205,85 \\
\hline 3. Net profit $(3=2-1)$ & 101,083 & 88,544 \\
\hline
\end{tabular}

Source: Analysis results from the author's research data

According to figures calculated that the net profit from the investment of households with a geographical indication is higher than the investment results of households without a geographical indication. Specific results: the group with geographical indications with an average net investment of VND 101,083 million; the group without a geographical indication had an average net investment of VND 88,544 million. Survey results and calculations are relatively appropriate when investment is high, household income will also be high, net profit from investment is also relatively high.

\section{Conclusion}

This research was conducted to analyze the results of investment in product development with geographical indications in Vietnam, Illustrative Examples: lychee products. The research findings are the foundation for helping policy makers to use as a base to proposed policy recommendations for the country, local to develop products with geographical indications. At the same time, research is also useful reference works for students in economic majors which can be used for reference. However, in the future, if it is possible expand the scope of the study with other products bearing geographical indications, Research findings will be better.

\section{Recommendations}

In order to invest in lychee product development to bring better results, some recommendations are proposed by the author as follows:

Training courses on processing and preserving lychee products need to be organized from which can choose a wider range of product consumption methods more diverse for producers.

Training for households producing/ farmers who growing agricultural products about market development skills

When skilled in market development and exposure to customer needs for products, producers will know what customer requirements about their products and will adjust to suit the tastes and meet market demand: including in both quality as well as requirements when packaging and harvesting products.

Strengthening support from competent state agencies to support people in credit loans, market access, rational use of resources in production and business of households, lychee growers to avoid input resource wasting 


\section{References}

Carina Folkeson, (2005), Geographical Indications and Rural Development in the EU, school of economics and management, Lund University, https://lup.lub.lu.se/luur/download?func=downloadFile\&recordOId=1334511\&fileOId= 1647280

Dominique Barjolle, Marguerite Paus, Anna Perret, (2009), Impacts of Geographical Indications Review of Methods and Empirical Evidence, International Association of Agricultural Economists Conference, Beijing, China, pp1-14, http://ageconsearch.umn.edu/bitstream/51737/2/PaperIAAE2009_85.pdf

Huynh Thi Dan Xuan and Mai Van Nam, (2011), Analysis of factors affecting the income of poultry farms in the Mekong Delta, Science Magazine - Can Tho University, vol 17b, pp8796

Hoang Trong and Chu Nguyen Mong Ngoc, (2008), Statistics in socio-economy, Statistical Publishing House

Le Dinh Thang, (1993), Household economic development toward commodity production, Agricultural Publishing House, Hanoi

Nguyen Sinh Cuc, (2001), rural survey analysis, Statistical Publishing House

Nguyen Thi Hong Hanh, Nguyen Thi Thanh Tra, Ho Thi Lam Tra, (2013), The impact of withdrawing agricultural land on lives of farmers in Van Lam district, Hung Yen province, Scientific journals and development, No. 1, episode 11

Nguyen Dinh Tho, (2012), Methods of scientific research in business: Design and implementation, Labor and Social Publishing House.

Nguyen Van Thang, (2014), research practices in economics and business administration course, National Economics University Publishing House

Nguyen Quoc Nghi, Bui Van Trinh, (2011), Factors affecting income of ethnic minorities in the Mekong Delta, scientific journals, vol 18a, pp240-250

Nguyen Quoc Nghi, (2011), Accessibility official capital of poor households. Banking Magazine, $7,12-19$

Nguyen Van Thieu, Nguyen Thi Ngoc Dung, (2014), Factors affecting livelihoods and sustainable livelihood solutions for people in flooded areas in An Giang province, scientific journals, 31, 39-45

Nguyen Van Toan et al, (2012), Effects of P135 programs on the livelihoods of ethnic minorities in Huong Hoa district, Quang Tri province, science - magazine- Hue University, 13 (72B), 356-362

Pradyot R. Jena, Ulrike Grot, (2010), Does geographical indication (GI) increase producer walfare? A case study of Basmati rice in Northern India, ISEE conference

Tabachnick, B.G., \& Fidell, L. S, (2007), Using multivariate statistics (3rded.), New York: Harper Collins

Vu Thi Minh, (2004), Developing fruit trees in mountainous areas of Quang Ninh province, National Economic University publishing house. 